\title{
UJI EFEK ANALGETIK EKSTRAK ETANOL BUAH TERONG BELANDA (Solanum betaceum) PADA MENCIT PUTIH GALUR SWISS WEBSTER
}

\author{
Wanda Satopa*, Eka Desnita*, Citra Lestari** \\ *Bagian Farmasi, FKG Universitas Baiturrahmah \\ **Bagian Periodonsian, FKG Universitas Baiturrahmah \\ E-mail : wandasatopa41@gmail.com
}

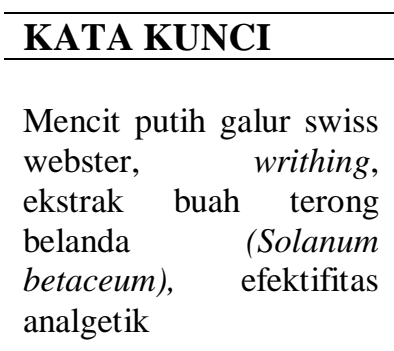

\section{KEYWORDS}

Mice galur swiss webster, Tamarillo extract (Solanum betaceum), analgetics effectiveness.

\begin{abstract}
ABSTRAK
Buah terong belanda merupakan salah satu tanaman yang tumbuh di Indonesia dan memiliki manfaat sebagai antioksidan karena mengandung nutrisi dan senyawa kimia yang sangat dibutuhkan oleh tubuh, yaitu vitamin (A, B1, B2, B6, C dan E), karoten, flavonoid dan serat. Flavonoid dapat mengurangi rasa nyeri dengan menghambat kerja enzim siklooksigenase. Penelitian ini dilakukan untuk mengetahui efek analgetik ekstrak buah terong belanda (Solanum betaceum) terhadap mencit putih galur swiss webster. Metode yang digunakan pada penelitian ini yaitu metode writhing dengan menggunakan 25 ekor mencit yang dibagi menjadi 5 kelompok yaitu kelompok kontrol negatif (CMC 1\%), kelompok kontrol positif (asam mefenamat 1,3 $\mathrm{mg} / 20 \mathrm{grBB}$ ) dan kelompok ekstrak buah terong belanda (dosis 1 $\mathrm{mg} / 20 \mathrm{grBB}, 2 \mathrm{mg} / 20 \mathrm{grBB}$ dan $4 \mathrm{mg} / 20 \mathrm{grBB}$ ) pada mencit putih jantan. Analisa statistik menggunakan uji Oneway ANOVA dengan nilai $\mathrm{p}=<0,05$. Hasil penelitian menunjukan bahwa pada dosis 4 $\mathrm{mg} / 20 \mathrm{gr} \mathrm{BB}$ dan dosis $2 \mathrm{mg} / 20 \mathrm{grBB}$ memiliki efek analgetik yang berbeda secara bermakna jika dibandingkan dengan kontrol negatif. Sedangkan dosis $1 \mathrm{mg} / 20 \mathrm{gr}$ BB tidak memiliki efek analgetik secara bermakna terhadap kontrol negatif. Pada dosis $4 \mathrm{mg} / 20 \mathrm{gr}$ BB memiliki efektifitas analgetik sebesar 116,9\% yang melebihi persen efektifitas analgesik kontrol positif. Ekstrak etanol buah terong belanda berpotensi untuk dikembangkan sebagai obat analgetik baru.
\end{abstract}


controls. The ethanol extract of tamarillo fruits has the potential to be developed as a new analgesic drug.

\section{PENDAHULUAN}

Kesehatan merupakan bagian yang terpenting dalam kehidupan manusia. Menurut Undangundang No. 36 tahun 2009 menyatakan bahwa kesehatan adalah keadaan sehat, baik secara fisik, mental, spiritual maupun sosial yang memungkinkan setiap orang untuk hidup produktif secara sosial dan ekonomi. Kesehatan gigi dan mulut merupakan bagian dari kesehatan tubuh yang tidak dapat dipisahkan dengan lainnya. Kesehatan gigi dan mulut mempengaruhi kesehatan seluruh tubuh ${ }^{1}$.

Derajat kesehatan yang optimal dapat mempengaruhi sumber daya manusia. Salah satu upaya meningkatkan derajat kesehatan yaitu dengan melakukan penelitian berupa penemuan obat-obat yang dapat mengatasi berbagai macam penyakit. Salah satunya yaitu obat tradisional. Obat tradisional adalah bahan atau paduan bahan atau ramuan bahan yang berupa bahan tumbuhan, bahan hewan, bahan mineral, sediaan sarian (galenik) atau campuran dari bahan tersebut yang secara turun-temurun telah digunakan untuk pengobatan dan dapat diterapkan sesuai dengan norma yang berlaku dalam masyarakat ${ }^{2}$.

Pemanfaatan bahan tumbuhan sebagai pengobatan secara tradisi sudah dilakukan oleh masyarakat Indonesia ${ }^{3}$. Dikarenakan obat tradisional memiliki efek samping yang sangat minim, dan mudah ditemukan dibandingkan jenis obat lainnya.

Indonesia kaya akan keanekaragaman hayati, kurang lebih ada 30.000 spesies tanaman dan baru ditemukan 940 spesies yang diyakini masyarakat dapat menjadi obat herbal yang berkhsiat ${ }^{4}$.

Survey yang dilakukan oleh PT. Esai pada tahun 1986 menemukan bahwa adanya 7.000 spesies tanaman obat tumbuh di Indonesia dan setara dengan 90 persen tanaman obat yang ada di seluruh Asia ${ }^{5}$. Terong belanda merupakan tanaman yang banyak terdapat di Indonesia bahkan mudah ditemukan dalam kehidupan sehari-hari dan telah digunakan masyarakat sebagai obat tradisional karena memiliki berbagai khasiat. Buah terong belanda berkhasiat menurunkan kadar glukosa darah, kadar kolesterol dan berat badan ${ }^{6}$. Buah terong belanda meningkatkan imunitas dan kesegaran tubuh, serta memperlancar metabolisme. Buah terong belanda bermanfaat juga sebagai antioksidan karena mengandung nutrisi dan senyawa kimia yang sangat butuhkan oleh tubuh yaitu vitamin (A, B1, B2, B6, C dan E), karoten, flavonoid dan serat ${ }^{7}$.

Hasil uji skrining fitokimia buah terong belanda menunjukkan bahwa ekstrak etanol buah terong belanda segar mengandung senyawa kimia gologan flavonoid, terpenoid, steroid, saponin, alkanoid dan tanin ${ }^{7}$. 
Flavonoid berkerja menghambat kerja enzim siklooksigenase dalam proses kerja analgesik. Oleh karena itu produksi prostaglandin oleh asam arakhidonat menurun sehingga dapat mengurangi rasa nyeri ${ }^{8}$.

Dokter gigi akan selalu dihadapkan pada keluhan terhadap gejala-gejala atau tandatanda yang mendorong pasien datang ke dokter gigi, salah satu gejala yang sering dikeluhkan pasien adalah nyeri. Nyeri pada gigi dapat menganggu aktivitas penderitanya sehingga dapat mempengaruhi kualitas hidupnya.

Masyarakat mengeluh sakit gigi tetapi tidak berobat $87 \%, 12,3 \%$ masyarakat yang mengeluh sakit gigi datang berobat ke fasilitas pelayanan kesehatan gigi sudah dalam keadaan terlambat sehingga dari ratarata $6,4 \%$ gigi yang rusak $4,4 \%$ gigi sudah dicabut dan $0,7 \%$ lebih memilih mencari pengobatan tradisional ${ }^{9}$.

Nyeri gigi dapat berasal dari pulpodentinal yang kompleks atau periapikal jaringan ${ }^{10}$. Salah satu nyeri gigi disebabkan oleh peradangan pada pulpa gigi, kejadian ini paling sering diakibatkan oleh karies gigi (gigi rusak). Hal ini dapat menjadi penyakit infektif pada manusia di seluruh dunia, termasuk anak sekolah yang terkena sebanyak 60-90\% dari anak sekolah di seluruh dunia ${ }^{11}$, oleh karena itu peneliti ingin meneliti tanaman buah terong belanda (Solanum betaceum) sebagai analgetik.

\section{METODE PENELITIAN}

Alat yang digunakan adalah botol maserasi, seperangkat alat rotary evaporator, jarum oral, spatel, beaker gelas, batang pengaduk, lumpang, gelas ukur, pipet tetes, spidol, stop watch, kapas, timbangan analitik, timbangan hewan, kadang mencit, sarung tangan dan masker.

Bahan yang digunakan adalah buah terong belanda (Solanum Betaceum) yang berasal dari Padang, mencit jantan putih, makanan mencit, aquadest. asam mefenamat 500mg, CMC Na (Carboxy Methyl Cellulose) 1\%, Etanol 96\%, dan larutan asam asetat 1\% ml.

\section{Prosedur Penelitian}

\section{Penyiapan hewan uji}

Penelitian ini menggunakan mencit jantan sebagai hewan uji, yang dibagi dengan metode random sampling ke dalam 5 kelompok dan masing-masing kelompok terdiri dari 5 ekor mencit. Kelompok I sebagai kontrol negatif, kelompok II sebagai kelompok positif dengan menggunakan asam mefenamat, kelompok III, IV, dan V sebagai kelompok eksperimental yang diberi ekstrak buah terong belanda dengan dosis 50 $\mathrm{mg} / \mathrm{kgBB}, 100 \mathrm{mg} / \mathrm{kgBB}$, dan $200 \mathrm{mg} / \mathrm{kgBB}$. Sebelum pengujian mencit diadaptasikan dengan dipuasakan selama 8 jam kemudian ditimbang. Berat badan mencit yang digunakan 20-30 gram.

\section{Pembuatan ekstrak buah terong belanda}

Sampel berupa buah terong belanda dibersihkan dengan air lalu dirajang, kemudian keringkan aginkan. Setelah kering 
buah terong belanda ditimbang sebanyak 3 $\mathrm{kg}$ kemudian direndam dalam etanol 96\% selama 6 hari sambil sesekali diaduk, lalu disaring, ampasnya dimaserasi lagi sebanyak dua kali. Kumpulan maserat diuapkan dengan rotary evaporator hingga didapatkan ekstrak mengental ${ }^{12}$.

Pembuatan suspensi CMC 1\%

Larutan CMC (Carboxy Methyl Cellulose) dibuat dengan melarutkan CMC $1 \mathrm{~g}$ ke dalam $10 \mathrm{ml}$ aquades, lalu aduk hingga mengembang dan gerus sampai homogen. Setelah itu tambahkan dengan aquades sampai volume $100 \mathrm{~mL}^{13}$.

\section{Dosis ekstrak buah terong belanda}

Konversi dosis larutan buah terong belanda yang digunakan dalam penelitian ini menggunakan dosis bertingkat yaitu :

Dosis 1: $50 \mathrm{mg} / \mathrm{KgBB}$

Dosis mencit 20 gram $(0,02 \mathrm{~kg})=50 \mathrm{mg} / \mathrm{Kg}$ BB $\times 0,02 \mathrm{~kg}=1 \mathrm{mg}$

$\mathrm{VaO}: 0,2 \mathrm{mg} / \mathrm{cc}$

Konsentrasi $=$ Dosis $\mathrm{x}$ BB Mencit

$$
\begin{aligned}
& =\frac{\frac{\mathrm{VaO}}{0 \mathrm{mg} / \mathrm{KgBB} \times 0.02 \mathrm{~kg}}}{0.2 \mathrm{mg} / \mathrm{cc}} \\
& =5 \mathrm{mg} / \mathrm{cc}
\end{aligned}
$$

Dosis 2: $100 \mathrm{mg} / \mathrm{KgBB}$

Dosis mencit 20 gram $(0,02 \mathrm{~kg})=100$ $\mathrm{mg} / \mathrm{Kg} \mathrm{BB} \times 0,02 \mathrm{~kg}=2 \mathrm{mg}$

$$
\begin{aligned}
\text { Konsentrasi } & =\frac{100 \mathrm{mg} / \mathrm{KgBB} \times 0.02 \mathrm{~kg}}{0.2 \mathrm{mg} / \mathrm{cc}} \\
& =10 \mathrm{mg} / \mathrm{cc}
\end{aligned}
$$

Dosis 3: $200 \mathrm{mg} / \mathrm{KgBB}$

Dosis mencit 20 gram $(0,02 \mathrm{~kg})=200$ $\mathrm{mg} / \mathrm{Kg} \mathrm{BB} \times 0,02 \mathrm{~kg}=4 \mathrm{mg}$

Konsentrasi $=200 \mathrm{mg} / \mathrm{KgBB} \times 0.02 \mathrm{~kg}$

$$
0.2 \mathrm{mg} / \mathrm{cc}
$$

$$
=20 \mathrm{mg} / \mathrm{cc}
$$

\section{Dosis asam mefenamat}

Kontrol positif pada sampel mengunakan obat analgetik asam mefenamat. Dosis dewasa pada manusia dengan BB 70 $\mathrm{kg}$ adalah $500 \mathrm{mg}$. Pada mencit dengan BB $20 \mathrm{~g}$ adalah 0,0026 (Octavianus, 2014).

Dosis mencit $=(500 \mathrm{mg} \times 0,0026) \times 20 \mathrm{~g}$ mencit

$$
\begin{aligned}
= & (1,3 \mathrm{mg} / 20 \mathrm{~g}) \times 20 \mathrm{~g} \\
& \text { mencit } \\
= & 1,3 \mathrm{mg} / \mathrm{kgBB}
\end{aligned}
$$

Jadi dosis asam mefenamat yang diberikan pada mencit sebanyak $1,3 \mathrm{mg} / \mathrm{kgBB}$.

\section{Perlakuan terhadap hewan uji}

Pada uji analgetik hewan percobaan dibagi menjadi 5 kelompok secara acak untuk setiap kelompok terdiri dari 5 ekor mencit yaitu:

1. Kelompok 1: Hewan percobaan diberikan kontrol negatif berupa suspensi CMC $1 \%$ diberikan secara per oral.

2. Kelompok 2: Hewan percobaan diberikan suspensi ekstrak buah terong belanda (Solanum Betaceum) dengan dosis $1 \mathrm{mg} / 20 \mathrm{grBB}$ secara per oral lalu diberikan asam asetat $1 \%$ secara peritonieal.

3. Kelompok 3: Hewan percobaan diberikan suspensi ekstrak buah terong 
belanda (Solanum betaceum) dengan dosis $2 \mathrm{mg} / 20 \mathrm{grBB}$ secara per oral lalu diberikan asam asetat $1 \%$ secara peritonieal.

4. Kelompok 4: Hewan percobaan diberikan suspensi ekstrak buah terong belanda (Solanum betaceum) dengan dosis $4 \mathrm{mg} / 20 \mathrm{grBB}$ secara per oral lalu diberikan asam asetat $1 \%$ secara peritonieal.

5. Kelompok 5: Hewan percobaan diberikan kontrol positif berupa suspensi asam mefenamat dengan dosis 1,3 $\mathrm{mg} / \mathrm{kgBB}$ diberikan secara per oral.

Amati dan hitung jumlah geliat mecit setiap 5 menit sampai menit ke 60 .

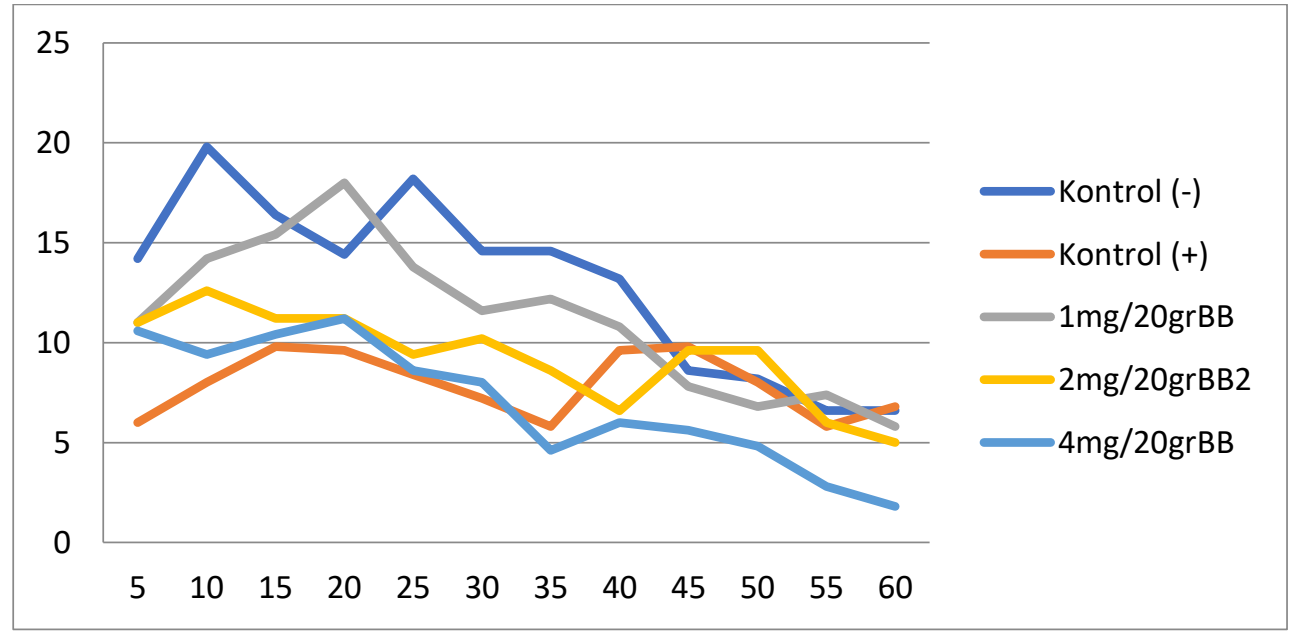

Gambar. Penyajian Analisis Data

Data hasil pengamatan respon mencit akan diolah dengan bentuk tabel, grafik dan analisis statistik uji one-way ANOVA (Analysis of Variance) dan dilanjutkan dengan pengujian LSD (Least Significant Difference).

\section{HASIL}

Hasil penelitian menunjukan rata-rata jumlah geliat efek analgetik pada kelompok

kontrol negatif yang diberikan CMC yaitu $(155,4 \pm 24)$, pada kontrol positif yaitu $(94,8 \pm 37,9)$, dosis I yaitu $(134,8 \pm 21,6)$, dosis II yaitu $(111 \pm 14,8)$, dosis III yaitu
$(83,8 \pm 20,1)$. Jumlah geliat paling sedikit yaitu pada dosis III dimana rata-rata geliatnya adalah 83,8 kali sedangkan jumlah geliat terbanyak yaitu pada kontrol negatif dengan rata-ratanya 155,4 kali.

Hasil analisis statistik uji ANOVA rata-rata total respon mencit kelompok kontrol negatif, kontrol positif dan kelompok perlakuan menunjukan hasil yang bermakna dengan nilai $\mathrm{p}=0.001(\mathrm{p}>\alpha)$, dan dilanjutkan dengan uji LSD yang menunjukan hasil dosis ekstrak etanol buah terong belanda yang paling berefek terhadap mencit yang dibandingkan dengan kontrol (-) 
secara berurutan yaitu dosis III, dosis II dan tidak berefek pada dosis I. Dosis III lebih memiliki efek dibandingkan dengan kontrol positif karena jumlah geliat yang paling sedikit.

Pengukuran rata-rata geliat mencit pada menit ke-5 sampai menit ke-25 mengalami peningkatan jumlah geliat dan setelah itu mengalami penurunan geliat pada menit seterusnya sampai menit ke-60.

\section{PEMBAHASAN}

Hasil uji skrining fitokimia buah terong belanda menunjukkan bahwa ekstrak etanol buah terong belanda segar mengandung senyawa kimia gologan flavonoid, terpenoid, steroid, saponin, alkanoid dan $\operatorname{tanin}^{7}$. Efek analgetik dari ekstrak etanol buah terong belanda (Solanum betaceum) ini diduga karena peran flavonoid yang terkandung dalam buah terong belanda (Solanum betaceum).

Flavonoid berkhasiat sebagai analgetik yang mekanisme kerjanya menghambat kerja enzim siklooksigenase sehingga dapat mengurangi produksi prostaglandin yang dapat mengurangi rasa nyeri ${ }^{14}$. Pada buah terong belanda juga terdapat steroid dengan kadar yang tinggi sehingga kerja analgetik akan menjadi lebih baik, karena steroid dapat menghambat fosfolipase sehingga menghalangi pembentukan prostaglandin dan leukotrien, sehingga efek analgetik menjadi lebih baik dari NSAIDs ${ }^{15}$. Jadi penurunan geliat mencit dikarenakan adanya kandungan flavonoid dan steroid yang menyebabkan pengurangan rasa nyeri.

Persentase proteksi terhadap induksi asam asetat pada mencit menunjukkan persentase proteksi terbesar yaitu pada kelompok dosis III $(46,07 \%)$ dan kontrol positif $(39,38 \%)$ artinya dosis I dan kontrol (+) merupakan dosis yang dapat menberikan efek analgetik. Sedangkan kelompok dosis I hanya memiliki persentase proteksi $13,25 \%$ dan dosis II memiliki persentase dosis 28,57 artinya dosis I dan dosis II tidak efektif menberikan efek analgetik karena memiliki proteksi minimal. Hasil persentasi efektifitas analgetik bahan uji kelompok dosis III melebihi persentase efektifitas dari kontrol positif yaitu 116,9\% terhadap kontrol positif, sehingga dosis III dapat memberikan efektifitas analgetik yang hampir setara dengan kontrol positif. Dosis II memiliki persen efektifitas yang mendekati persentase kontrol positif yaitu 72,54\%, Sedangkan kelompok dosis I hanya memiliki persentase efektifitas analgetik 33,64\% dimana persentasenya masih beda jauh dengan kontrol positif dengan demikian dosis I tidak efektif memberikan efek analgetik. Namun kelompok dosis yang memiliki efek analgetik maksimal adalah pada kelompok dosis III.

Kontrol positif yang digunakan adalah asam mefenamat yang jumlah rata-rata geliat yang dihasilkan adalah 94,8 setara dengan dosis III 83,8 dengan asam mefenamat dan dosis III diartikan dosis III lebih tinggi 3 kali dari dosis asam mefenamat karena kandungan 
flavonoid dari buah terong belanda yang sedikit. Flavonoid diduga menghambat enzim nyeri sehingga dapat mengurangi rasa nyeri.

\section{SIMPULAN}

Hasil penelitian ini dapat disimpulkan bahwa ekstrak buah terong belanda (Solanum betaceum) dapat mengurangi jumlah geliat pada mencit yang diinduksi asam asetat pada dosis II dan dosis III dibandingkan dengan kontrol negatif. Sedangkan dosis I tidak memiliki efek analgetik terhadap kontrol negatif. Kelompok dosis III memiliki efektifitas analgetik yang hampir setara dengan kontrol positif (asam mefenamat).

\section{DAFTAR PUSTAKA}

1. Nainggolan, S. J., \& Anjelina, N. (2016). Gambaran Ph Saliva Terhadap Karies Gigi Pada Siswa/i Kelas IV SD Negeri 065015 Kementrian Tani Medan Tuntugan. Jurnal Ilmiah PANNMED, 11(2), 74-76.

2. Kemenkes. (2009). Undang-undang Republik Indonesia No. 36 Tahun 2009 Tentang Kesehatan. Undang-Undang Republik Indonesia, 1-48.

3. Rivai, H., Heriadi, A., \& Fadhilah, H. (2015). Pembuatan dan Karakterisasi Ekstrak Kering Daun Salam (Syzigium Polyanthum (WIGHT) WALP.). Jurnal Faemasi Higea, 7(1), 54-36.

4. Sibarani, V. R., Wowor, P. M., \& Awaloei, H. (2013). Uji Efek Analgesik Ekstrak Daun Beluntas (Pluchea indica (L.) Less.) Pada Mencit (Mus musculus). Jurnal E-Biomedik (eBM), l(1), 873-878.

5. Atun, S. (2007). Pemanfaatan Bahan Alam Bumi Indonesia Menuju Riset Yang Berkualitas Internasional. 101.203.168.85, 115. Retrieved from http://101.203.168.85/sites/default/files/Pema nfaatan bahan alam Indonesia menuju riset yang berkualitas internasional-SemNas Kimia-2010.pdf

6. Asvita, S. M., \& Berawi, K. N. (2016). Efektivitas Ekstrak Terong Belanda untuk Menurunkan Kadar Glukosa dan Kolesterol LDL Darah pada Pasien Obesitas. Majority, 5(1), 102-106.

7. Dewi, N. W. O. A. C. D., Puspawati, N. M., Swantara, I. M. D., Asih, I. A. R. . A., \& Rita, W. S. (2014). Aktivitas Antioksidaan Senyawa Flavonoid Ekstrak Etanol Biji Terong Belanda (Solanum betaceum, syn) dalam Menghambat Reaksi Peroksidasi Lemak pada Plasma Darah Tikus Wistar. Cakra Kimia Indonesain E-Journal of Applied Chemistry, 2(1), 7-16.

8. Octavianus, S., \&, Fatimawali, dan W. A. L. (2014). Uji Efek Analgetik Ekstrak Etanol Daun PEepaya (Carica papaya L) pada Mencit Putih Jantan (Mus mucculus). Pharmacon Jurnal Ilmiah Farmasi, 3(2), 8792.

9. Kushayati, N. (2011). Efektifitas Kumur Air Garam Terhadap Penurunan Nyeri Pada Penderita Nyeri Gigi Di Sumolepen Kelurahan Balongsari Kota Mojokerto. Jurnal Keperawatan, 1(1), 11.

10. Prpic-Mehicic, G., \& Galic, N. (2010). Odontogenic pain. Rad 507. Medical Sciences, 34, 43-54.

11. Renton, T. (2011). Dental (Odontogenic) Pain. Reviews in Pain, 5(1), 2-7.

12. Afrianti, R., Yenti, R., \& Meustika, D. (2014). Uji Aktifitas Analgetik Ekstrak Etanol Daun Pepaya (Carica papaya L.) pada Mencit Putih Jantan yang di Induksikan Asam Asetat $1 \%$. Jurnal Sains Farmasi, 1(1), 54-60.

13. Bakarbessy, W. H. A., Wullur, A. C., \& Lolo, W. A. (2016). Uji Efek Analgesik Ekstrak Etanol Daun Sukun (Artocarpus altilis) pada Tikus Putih Galur Wistar (Rattus norvegicus). Pharmacon Jurnal Ilmiah Farmasi, 5(2), 220227.

14. Syamsul, E. S., Andani, F., \& Soemarie, Y. B. (2016). Analgesik Activity Study of Ethanolic Extract Callicarpa longifolia Lamk .IN MICE. Traditional Medicine Journal, 21(2), 99-103.

15. Safitri, Arrany R. (2013). Uji Efek Analgetik Infusia Daun Cocor Bebek (Kalanchoe pinnata (Lam.)Pers) Terhadap Mencit Jantan Galur Swiss yang Diinduksikan Asam Asetat. Naskah Publikasi. Fakultas Kedokteran Universitas Tanjungpura Pontianak. 